\title{
Acute exposure to 3-deoxyglucosone at high glucose levels impairs insulin secretion from $\beta$-cells by downregulating the sweet taste receptor signaling pathway
}

\author{
XIUDAO SONG ${ }^{*}$, GUOQIANG LIANG*, MIN SHI, LIANG ZHOU, FEI WANG, \\ LURONG ZHANG, FEI HUANG and GUORONG JIANG \\ Basic Research Laboratory, Suzhou Academy of Wumen Chinese Medicine, Suzhou TCM Hospital \\ Affiliated to Nanjing University of Chinese Medicine, Suzhou, Jiangsu 215009, P.R. China
}

Received September 24, 2018; Accepted April 10, 2019

DOI: $10.3892 / \mathrm{mmr} .2019 .10163$

\begin{abstract}
Sweet taste receptors (STRs) expressed on $\beta$-cells stimulate insulin secretion in response to an increase in the circulating level of glucose, maintaining glucose homeostasis. 3 -Deoxyglucosone (3DG), a highly reactive $\alpha$-dicarbonyl compound, has been previously described as an independent factor associate with the development of prediabetes. In our previous study, pathological plasma levels of 3DG were induced in normal rats with a single intravenous injection of $50 \mathrm{mg} / \mathrm{kg}$ 3DG, and an acute rise in circulating 3DG induced glucose intolerance by impairing the function of pancreatic $\beta$-cells. The present study aimed to investigate whether the deleterious effects of pathological plasma levels of 3DG on $\beta$-cell function and insulin secretion were associated with STRs. INS-1 cells, an in vitro model to study rat $\beta$-cells, were treated with various concentrations of 3DG $(1.85,30.84$ and $61.68 \mathrm{mM})$ or lactisole $(5 \mathrm{mM})$. Pancreatic islets were collected from rats $2 \mathrm{~h}$ after a single intravenous injection of $50 \mathrm{mg} / \mathrm{kg} 3 \mathrm{DG}+0.5 \mathrm{~g} / \mathrm{kg}$ glucose. The insulin concentration was measured by ELISA. The protein expression levels of components of the STR signaling pathways were determined by western blot analysis. Treatment with 3DG and $25.5 \mathrm{mM}$ glucose for $1 \mathrm{~h}$ significantly reduced insulin secretion by INS-1 cells, which was consistent with the phenotype observed in INS-1 cells treated with the STR inhibitor lactisole. Accordingly, islets isolated from rats treated with 3DG exhibited a significant reduction in insulin secretion following treatment with $25.5 \mathrm{mM}$ glucose.
\end{abstract}

Correspondence to: Professor Guorong Jiang, Basic Research Laboratory, Suzhou Academy of Wumen Chinese Medicine, Suzhou TCM Hospital Affiliated to Nanjing University of Chinese Medicine, 18 Yangsu Road, Suzhou, Jiangsu 215009, P.R. China E-mail: szguorongjiang@163.com

${ }^{*}$ Contributed equally

Key words: 3-deoxyglucosone, taste 1 receptor member 3, sweet taste receptors, insulin secretion, INS-1 cells
Furthermore, acute exposure of INS-1 cells to 3DG following treatment with $25.5 \mathrm{mM}$ glucose for $1 \mathrm{~h}$ significantly reduced the protein expression level of the STR subunit taste 1 receptor member 3 and its downstream factors, transient receptor potential cation channel subfamily $\mathrm{M}$ member 5 and glucose transporter 2. Notably, islet tissues collected from rats treated with 3DG exhibited a similar downregulation of these factors. The present results suggested that acute exposure to pathologically relevant levels of 3DG in presence of high physiological levels of glucose decreased insulin secretion from $\beta$-cells by, at least in part, downregulating the STR signaling pathway.

\section{Introduction}

Glucose is the main physiological stimulator of insulin release, and the mechanism by which glucose regulates insulin secretion has been investigated for several decades. It is known that the regulation of insulin secretion is mediated by signals involved in glucose metabolism. Glucose enters $\beta$-cells via the glucose transporter 2 (GLUT2) and it is metabolized via the glycolytic pathway, whose downstream signaling pathway induces insulin secretion (1). A recent study identified that glucose-sensing receptors in $\beta$-cells are involved in regulating the effect of glucose on insulin secretion (2). The sweet taste receptors (STRs) are heterodimers formed by two members of the class C G protein-coupled receptor family, taste 1 receptor member (T1R) 2 and T1R3 (3). STRs have been identified to function as a glucose-sensing receptor in the taste cells of the tongue (3). When STRs are activated by sugar molecules, the signal is transduced to a taste-cell-specific trimeric G protein, gustducin, and the subsequent activation of phospholipase C- $\beta 2$ (PLC $\beta 2$ ) leads to the inositol 1,4,5-trisphosphate-mediated release of $\mathrm{Ca}^{2+}$ from intracellular stores $(4,5)$. The increase in intracellular $\mathrm{Ca}^{2+}$ activates the monovalent cation-specific transient receptor potential cation channel subfamily $\mathrm{M}$ member 5 (TRPM5), leading to $\mathrm{Na}^{+}$influx and depolarization of the cell $(4,5)$. In addition to the taste cells of the tongue, STR subunits are also found in mouse and human $\beta$-cells $(6,7)$. It was demonstrated that STRs are associated with the PLC $\beta 2 / T R P M 5$ cascade in $\beta$-cells (6). However, compared with T1R3, the expression level of T1R2 is lower in islets and 
in the pancreatic $\beta$-cell line MIN6 (7). Knockdown of T1R3 attenuates the effect of the sweetener acesulfame $\mathrm{K}$, whereas knockdown of T1R2 does not affect the action of acesulfame K (8). T1R3 knockdown in MIN6 cells also decreases the amount of intracellular ATP and the insulin secretion following stimulation with $25 \mathrm{mM}$ glucose (9). Therefore, these previous findings indicated that T1R3 may be important for glucose sensing and for the regulation of insulin secretion induced by high concentrations of glucose.

3 -Deoxyglucosone (3DG), a highly reactive $\alpha$-dicarbonyl compound, is formed from carbohydrates during food processing and storage, and it is also produced by living organisms $(10,11)$. The clinical significance of $3 D G$ is associated with its ability to react with certain proteins to form advanced glycation end products that are involved in the pathogenesis of diabetic complications (12). Accumulating evidence demonstrated that the plasma levels of 3DG in diabetic patients are increased by $\sim 2$ folds compared with healthy subjects $(13,14)$. Collectively, these previous studies indicate the role of 3DG in the pathogenesis of diabetic complications. Our previous animal and clinical studies have demonstrated that $3 D G$ is an independent factor associated with the development of prediabetes (15-19). Additionally, our previous studies showed that an abnormal increase of 3DG leads to the impairment of pancreatic $\beta$-cell function $(15,18)$. In addition, increased plasma levels of 3DG after glucose stimulation was observed in normal subjects and patients with impaired glucose metabolism (20). In our previous study, pathologically relevant plasma levels of 3DG were induced in normal rats with a single intravenous (i.v.) injection of $50 \mathrm{mg} / \mathrm{kg} 3 \mathrm{DG}$, and an acute rise in the circulating levels of 3DG induced glucose intolerance, thus impairing the function of pancreatic $\beta$-cells (19), suggesting the potential involvement of 3DG in the increased risk of glucose intolerance in patients with postprandial glucose excursions. However, the role of STRs on the deleterious effects of pathologically relevant plasma levels of 3DG on $\beta$-cells function at high physiological glucose levels remains unknown.

A previous study identified that the expression of the STR subunit T1R3, $\alpha$-gustducin and TRPM5 are downregulated in the ileum of Zucker diabetic fa/fa rats (21). In line with this previous study, our previous study identified that the protein expression levels of STR and its downstream factor TRPM5 are downregulated in duodenal and colon tissues following a 2-week administration of $50 \mathrm{mg} / \mathrm{kg}$ 3DG intragastric (i.g.) in rats exhibiting a prediabetic condition (16). Additionally, in the pancreatic islets of diabetic and diet-induced obese mice, the protein expression levels of the STR subunits were downregulated $(22,23)$. Furthermore, in vitro experiments suggested that the downregulation of the expression level of STR genes is involved in the impairment of the STR-mediated insulin secretion by $\beta$-cells $(22,23)$. Our previous study identified that acute exposure of STC-1 L-cells to 3DG in the presence of $25 \mathrm{mM}$ glucose for $1 \mathrm{~h}$ was able to downregulate the expression level of STR, decreasing STR-mediated zinc finger GATA like protein 1 (GLP-1) secretion (24). Therefore, 3DG may exhibit deleterious effects on the STR signaling pathways. Altogether, it is possible that the deleterious effects on glucose tolerance caused by an acute increase in circulating 3DG may be associated with the impairment of $\beta$-cell function mediated by the downregulation of the STR signaling pathway in $\beta$-cells.
Accumulating evidence has demonstrated that stimulation of insulin secretion by high concentrations of glucose involves STRs (2). Therefore, the present study aimed to investigate the in vivo and in vitro effects of pathologically relevant plasma levels of 3DG on insulin secretion and STR signaling in $\beta$-cells at high physiological glucose levels. After acute exposure of INS-1 cells to 3DG $(1.85,30.84$ and $61.68 \mathrm{mM})$ in the presence of $25.5 \mathrm{mM}$ glucose for $1 \mathrm{~h}$, insulin secretion and the expression levels of components of the STR signaling pathways were examined. Insulin secretion at glucose concentrations of 5.6 and $25.5 \mathrm{mM}$ and the expression levels of components of the STR signaling pathways were also examined in pancreatic islets collected from rats after a single i.v. injection of $50 \mathrm{mg} / \mathrm{kg}$ $3 \mathrm{DG}+0.5 \mathrm{~g} / \mathrm{kg}$ glucose .

\section{Materials and methods}

Reagents. 3DG was synthesized following a modified method reported by Kato et al (25), as previously described (26). Lactisole purchased from Sigma-Aldrich (Merck KGaA) was dissolved in DMSO, and the final concentration of DMSO was adjusted to $0.05 \%$ for all conditions tested.

Animals and cell culture. Male Sprague-Dawley rats (age, 11 weeks; weight $\sim 200 \mathrm{~g}$ ) purchased from the JOINN Laboratories were housed at $20-23^{\circ} \mathrm{C}$ with a relative humidity of 50-60\%) and under a 12-h light/dark cycle, in accordance with the European Union Directive 2010/63/EU for animal experiments (27). All the animal protocols were approved by The Local Committee on Ethics of Animal Experiments of Suzhou TCM Hospital Affiliated to Nanjing University of Chinese Medicine (Suzhou, China). The rats were allowed free access to food and water, and were fed a standard rat diet (Shuangshi Laboratory Animal Feed Science Co., Ltd.). After 1 week of acclimatization, eighteen rats were randomly divided into the experimental groups ( $\mathrm{n}=6$ in each group). The rats were fasted overnight before the experiments. A single i.v. injection of $0.9 \%$ saline (control), $0.5 \mathrm{~g} / \mathrm{kg}$ glucose or $50 \mathrm{mg} / \mathrm{kg} 3 \mathrm{DG}+0.5 \mathrm{~g} / \mathrm{kg}$ glucose was administered to the rats. The insulin-secreting INS-1 rat $\beta$-cells were obtained from Soochow University (Suzhou, China) and were cultured as previously described (18). INS-1 cells were cultured in RPMI-1640 (Gibco; Thermo Fisher Scientific, Inc.) containing $11.2 \mathrm{mM}$ glucose, 10\% FBS (Gibco; Thermo Fisher Scientific, Inc.) and $50 \mu \mathrm{M} \beta$-mercaptoethanol (Sigma-Aldrich; Merck $\mathrm{KGaA}$ ) in a humidified incubator with $5 \% \mathrm{CO}_{2}$ at $37^{\circ} \mathrm{C}$.

Rat islet isolation and culture. After overnight fasting, rats were anesthetized by intraperitoneal injection of $100 \mathrm{mg} / \mathrm{kg}$ pentobarbital sodium (Sigma-Aldrich; Merck KGaA) and were administered a single i.v. injection of $0.5 \mathrm{~g} / \mathrm{kg}$ glucose or $50 \mathrm{mg} / \mathrm{kg} 3 \mathrm{DG}+0.5 \mathrm{~g} / \mathrm{kg}$ glucose. After $2 \mathrm{~h}$, the anesthetized rats were sacrificed by $\mathrm{CO}_{2}$ exposure (displacement rate, $20 \% / \mathrm{min}$ ). If no breath was observed for $\geq 60 \mathrm{sec}$, the sacrificed rodent was removed from the chamber and pancreatic islets were isolated using the collagenase method, as previously described (19). The pancreas was removed and digested by incubation in DMEM (Sigma-Aldrich; Merck KGaA) supplemented with collagenase $(1.5 \mathrm{mg} / \mathrm{ml})$. The digested pancreas was filtered and centrifuged at $1,000 \mathrm{x}$ gat $4^{\circ} \mathrm{C}$ for $3 \mathrm{~min}$. The 
isolated islets were cultured in RPMI-1640 culture medium containing $11.2 \mathrm{mM}$ glucose and $10 \%$ fetal calf serum (Gibco; Thermo Fisher Scientific, Inc.) in a humidified incubator with $5 \% \mathrm{CO}_{2}$ at $37^{\circ} \mathrm{C}$. The islets were subsequently used for the measurement of insulin secretion and western blot analysis.

Measurement of insulin concentration in INS-1 cells and rat islets. INS-1 cells $\left(4 \times 10^{3}\right.$ cells/well) were seeded in 96-well plates in RPMI-1640 culture medium containing $11.2 \mathrm{mM}$ glucose and cultured overnight. The cells were incubated in RPMI-1640 containing $25.5 \mathrm{mM}$ glucose for $1 \mathrm{~h}$ in the presence or absence of 3DG $(1.85,30.84$ and $61.68 \mathrm{mM})$ or lactisole $(5 \mathrm{mM})$, and the supernatant from the medium was collected for the measurement of insulin concentration. Islets were harvested from fasting rats $2 \mathrm{~h}$ after a single i.v. injection of $0.5 \mathrm{~g} / \mathrm{kg}$ glucose or $50 \mathrm{mg} / \mathrm{kg} 3 \mathrm{DG}+0.5 \mathrm{~g} / \mathrm{kg}$ glucose. In total, 30 islets were isolated from 3DG-treated rats and were immediately cultured in RMPI-1640 containing $5.6 \mathrm{mM}$ glucose for $1.5 \mathrm{~h}$. Subsequently, insulin secretion under different conditions were assessed.

Following the indicated treatment, INS-1 cells or islets from 3DG-treated rats were transferred to RMPI-1640 containing $5.6 \mathrm{mM}$ glucose for $1.5 \mathrm{~h}$. For basal insulin secretion measurement, INS-1 cells or 30 islets were incubated with $5.6 \mathrm{mM}$ glucose in RPMI-1640 for $1.5 \mathrm{~h}$. For glucose-stimulated insulin secretion measurement, INS-1 cells or islets were incubated with $25.5 \mathrm{mM}$ glucose in RPMI-1640 for $1 \mathrm{~h}$. The insulin concentration in the supernatant was measured using a rat insulin ELISA kit (cat. no. EZRMI-13K; Linco Research, Inc.; EMD Millipore) according to the manufacturer's protocol.

Western blot analysis. INS-1 cells grown to confluence in 6 -well dishes were incubated with various concentrations of 3DG $(1.85,30.84$ and $61.68 \mathrm{mM})$ in RPMI-1640 culture medium containing $25.5 \mathrm{mM}$ glucose for $1 \mathrm{~h}$. The cells were subsequently transferred to RPMI-1640 culture medium containing $5.6 \mathrm{mM}$ glucose for $1.5 \mathrm{~h}$. Then, $2 \mathrm{~h}$ after a single i.v. injection of vehicle ( $0.9 \%$ saline, control group), $0.5 \mathrm{~g} / \mathrm{kg}$ glucose or $50 \mathrm{mg} / \mathrm{kg} 3 \mathrm{DG}+0.5 \mathrm{~g} / \mathrm{kg}$ glucose, the pancreatic islets were isolated from rats. In total, 100 islets were then transferred to RPMI-1640 culture medium containing $5.6 \mathrm{mM}$ glucose for $1.5 \mathrm{~h}$. INS-1 cells and islets were homogenized in a lysis buffer containing $1 \%$ Triton X-100, protease inhibitors and phosphatase inhibitors (Beyotime Institute of Biotechnology). Western blot analysis was performed using INS-1 cells and isolated pancreatic islets as previously described $(18,19)$. The total protein concentration was determined using a bicinchoninic acid protein assay kit (cat. no. P0012; Beyotime Institute of Biotechnology). In total, $50 \mu \mathrm{g}$ protein from each sample was separated by SDS-PAGE. Proteins were transferred onto PVDF membranes (Merck KGaA). The membranes were blocked for $1 \mathrm{~h}$ at room temperature in Tris-buffered saline with $1 \%$ Tween (Beijing Solarbio Science \& Technology Co., Ltd.) containing 5\% dry milk. The membranes were incubated with the appropriate primary antibody at $4^{\circ} \mathrm{C}$ overnight. Subsequently, membranes were incubated with horseradish peroxidase-conjugated goat anti-rabbit (1:5,000; cat. no. AT0097; CMCTAG, Inc.), goat anti-mouse (1:1,500; cat. no. AT0098; CMCTAG, Inc.) or rabbit anti-goat (1:1,500; cat. no. AT0101; CMCTAG, Inc.) secondary antibodies at room temperature for $2 \mathrm{~h}$. The blots were detected with an enhanced chemiluminescence-kit (Beyotime Institute of Biotechnology) followed by autoradiography. The amount of protein loaded was confirmed by stripping the blots using restore western blot stripping buffer (cat. no. 21509; Thermo Scientific, Inc.) and reprobing them using an anti- $\beta$-actin antibody (dilution, 1:1,000; cat. no. AT0001; CMCTAG, Inc.). The primary antibodies used for western blot were as follows: Anti-T1R3 (1:200; cat. no. sc-22458; Santa Cruz Biotechnology, Inc.), anti-TRPM5 (1:167; cat. no. ab87642; Abcam) and anti-GLUT2 (1:100; cat. no. ab54460; Abcam). The intensity of the bands was analyzed using the SpotDenso tool of the built-in software of the detection instrument (Alphaimager 2200; ProteinSimple).

Statistical analysis. All presented data are representative of $\geq 3$ independent experiments. Data are presented as the mean \pm SD. Comparisons were performed using Student's t-test or one-way ANOVA followed by Bonferroni's post-hoc test. Statistical analyses were performed using Prism (version 5; GraphPad Software, Inc.). $\mathrm{P}<0.05$ was considered to indicate a statistically significant difference.

\section{Results}

Treatment with the STR inhibitor lactisole impairs insulin secretion in INS-1 cells. The role of STRs on insulin secretion in response to high concentrations of glucose in INS-1 $\beta$-cells was examined (Fig. 1). INS-1 cells were treated with the STR inhibitor lactisole at a concentration of $5 \mathrm{mM}$ in the presence of $25.5 \mathrm{mM}$ glucose for $1 \mathrm{~h}$, and the concentration of insulin in the supernatant was subsequently measured. Insulin secretion in response to $25.5 \mathrm{mM}$ glucose stimulation was reduced to $81 \%$ in the presence of lactisole (Fig. 1A). Subsequently, INS-1 cells treated with lactisole were incubated at different concentrations of glucose to examine basal and glucose-stimulated insulin secretions. INS-1 cells pretreated with lactisole and $25.5 \mathrm{mM}$ glucose showed an increased basal insulin secretion in response to $5.6 \mathrm{mM}$ glucose, whereas glucose-stimulated insulin secretion was significantly lower in INS-1 exposed to $25.5 \mathrm{mM}$ glucose, and insulin secretion was reduced to $83 \%$ (Fig. 1B). The present findings suggested that the pharmacologic inhibition of STRs in INS-1 rat $\beta$-cells impaired insulin secretion in response to $25.5 \mathrm{mM}$ glucose stimulation.

Acute exposure of INS-1 cells to $3 D G$ and $25.5 \mathrm{mM}$ glucose for $1 \mathrm{~h}$ impairs insulin secretion. Following the same experimental conditions used for the lactisole treatment, INS-1 cells were exposed to pathologically relevant concentrations of 3DG at high concentrations of glucose, and insulin secretion was subsequently examined. INS-1 cells were treated with various concentrations of 3DG $(1.85,30.84$ and $61.68 \mathrm{mM})$ at $25.5 \mathrm{mM}$ glucose for $1 \mathrm{~h}$ and the insulin concentration in the supernatant was measured. Following treatment with 1.85, 30.84 , and $61.68 \mathrm{mM} 3 \mathrm{DG}$, the insulin secretion in response to $25.5 \mathrm{mM}$ glucose stimulation was reduced to 89,83 and $84 \%$, respectively (Fig. 2A). Subsequently, INS-1 cells were pretreated with $3 \mathrm{DG}$ for $1 \mathrm{~h}$, and insulin secretion was measured following exposure to $5.6 \mathrm{mM}$ glucose for $1.5 \mathrm{~h}$ or $25.5 \mathrm{mM}$ glucose for $1 \mathrm{~h}$. Exposure to 30.84 and $61.68 \mathrm{mM}$ 

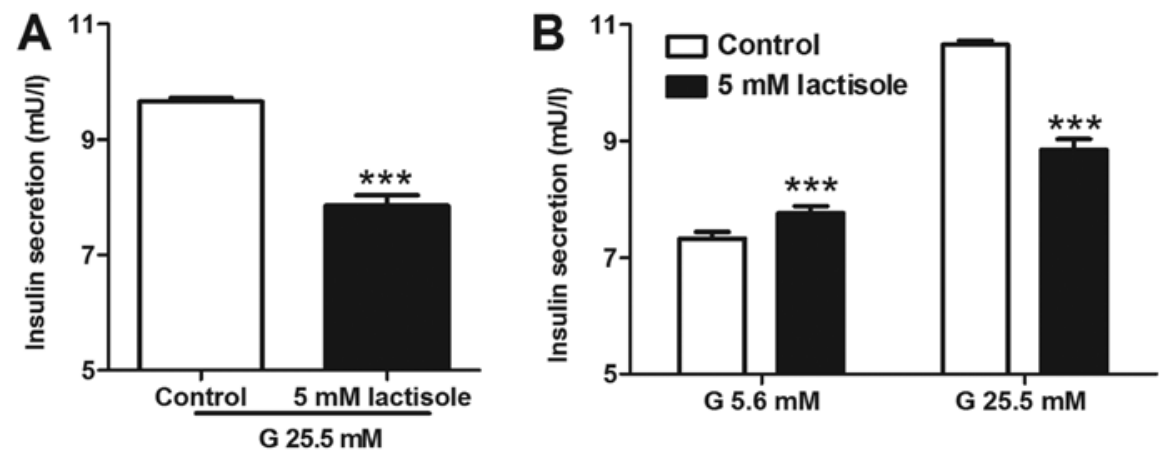

Figure 1. Exposure to the sweet taste receptor inhibitor, lactisole, for $1 \mathrm{~h}$ at $25.5 \mathrm{mM}$ glucose impairs insulin secretion in INS-1 cells. (A) INS-1 cells were incubated for $1 \mathrm{~h}$ with $25.5 \mathrm{mM}$ glucose in the presence or absence of $5 \mathrm{mM}$ lactisole. Subsequently, insulin concentration in the supernatant was measured. (B) INS-1 cells were pretreated with $5 \mathrm{mM}$ lactisole at $25.5 \mathrm{mM}$ glucose. Then, INS-1 cells were transferred to RMPI-1640 containing $5.6 \mathrm{mM}$ glucose for $1.5 \mathrm{~h}$. Next, INS-1 cells were stimulated for $1.5 \mathrm{~h}$ with $5.6 \mathrm{mM}$ glucose or for $1 \mathrm{~h}$ with $25.5 \mathrm{mM}$ glucose and the insulin concentration in the supernatant was measured. ${ }^{* * *} \mathrm{P}<0.001$ vs. control. $\mathrm{n}=6$. G, glucose.
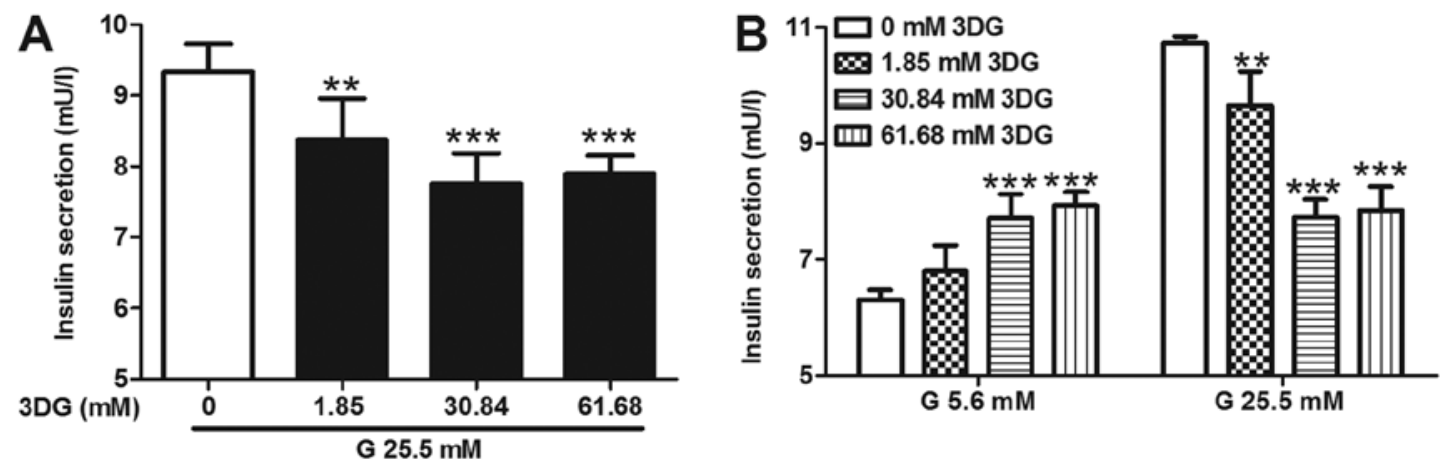

Figure 2. Acute exposure of INS-1 cells to 3DG at $25.5 \mathrm{mM}$ glucose for $1 \mathrm{~h}$ impairs insulin secretion. (A) INS-1 cells were incubated for $1 \mathrm{~h}$ with $25.5 \mathrm{mM}$ glucose in the absence or presence of 3DG at $1.85,30.84$ or $61.68 \mathrm{mM}$. Insulin concentration in the supernatant was subsequently measured. (B) INS-1 cells were pretreated with 3DG at $25.5 \mathrm{mM}$ glucose. Then, INS-1 cells were transferred to RMPI-1640 containing $5.6 \mathrm{mM}$ glucose for $1.5 \mathrm{~h}$. Next, insulin secretion in INS-1 cells was measured following exposure to $5.6 \mathrm{mM}$ glucose for $1.5 \mathrm{~h}$ or $25.5 \mathrm{mM}$ glucose for $1 \mathrm{~h} .{ }^{* *} \mathrm{P}<0.01,{ }^{* * *} \mathrm{P}<0.001 \mathrm{vs} .0 \mathrm{mM} 3 \mathrm{DG}$. n=6. 3DG, 3-deoxyglucosone; G, glucose.

3DG increased basal insulin secretion in response to $5.6 \mathrm{mM}$ glucose by 22 and 26\%, respectively (Fig. 2B). Following treatment with 30.84 and $61.68 \mathrm{mM}$ 3DG, glucose-stimulated insulin secretion in response to $25.5 \mathrm{mM}$ glucose was reduced to 71 and $73 \%$, respectively (Fig. 2B). The present results were consistent with the aforementioned lactisole treatment results (Fig. 1). Collectively, the present results suggested that acute exposure of INS-1 cells to pathologically relevant concentrations of 3DG at high concentrations of glucose impaired insulin secretion from $\beta$-cells in vitro.

Acute exposure of INS-1 cells to $3 D G$ at $25.5 \mathrm{mM}$ glucose for $1 \mathrm{~h}$ decreases the activity of the STR signaling pathway. The effects of pathologically relevant plasma levels of 3DG for $1 \mathrm{~h}$ at $25.5 \mathrm{mM}$ glucose on the protein expression levels of members of the STR pathway were investigated in INS-1 cells. INS-1 cells were exposed to various concentration of 3DG $(1.85,30.84$ and $61.68 \mathrm{mM})$ in the presence of $25.5 \mathrm{mM}$ glucose for $1 \mathrm{~h}$, and the protein expression levels of T1R3 were measured after a 1.5 -h incubation with $5.6 \mathrm{mM}$ glucose. Treatment with 3DG at various concentrations significantly reduced the protein expression levels of T1R3, TRPM5 and GLUT2 (Fig. 3). The present results suggested that acute exposure of INS-1 cells to pathologically relevant concentrations of $3 \mathrm{DG}$ for $1 \mathrm{~h}$ at $25.5 \mathrm{mM}$ glucose was sufficient to reduce the protein expression levels of members of the STR signaling pathway.

Impairment of insulin secretion and downregulation of the STR signaling pathway are induced in islets exhibiting glucose intolerance induced by acute exposure to $3 D G$. The effects of glucose intolerance induced by acute exposure to 3DG on insulin secretion and on the expression levels of members of the STR signaling pathway were investigated. Islets from fasting rats were collected $2 \mathrm{~h}$ after i.v. administration of $50 \mathrm{mg} / \mathrm{kg}$ $3 \mathrm{DG}+0.5 \mathrm{~g} / \mathrm{kg}$ glucose. Subsequently, islets were incubated with $5.6 \mathrm{mM}$ glucose for $1.5 \mathrm{~h}$, and insulin secretion in response to $5.6 \mathrm{mM}$ glucose for 1.5 or $25.5 \mathrm{mM}$ glucose for $1 \mathrm{~h}$ was assessed. Islets isolated from rats treated with 3DG exhibited a $21 \%$ increase in basal insulin secretion, at $5.6 \mathrm{mM}$ glucose (Fig. 4A). By contrast, glucose-stimulated insulin secretion ( $25.5 \mathrm{mM}$ glucose) decreased to $90 \%$. The protein expression levels of the members of the STR signaling pathways in islets isolated from 3DG-treated rats were subsequently measured. The protein expression levels of T1R3 and TRPM5 in islets collected from rats treated with $0.5 \mathrm{~g} / \mathrm{kg}$ glucose were significantly reduced compared with the control groups, whereas the protein expression level of GLUT2 was significantly increased 
A
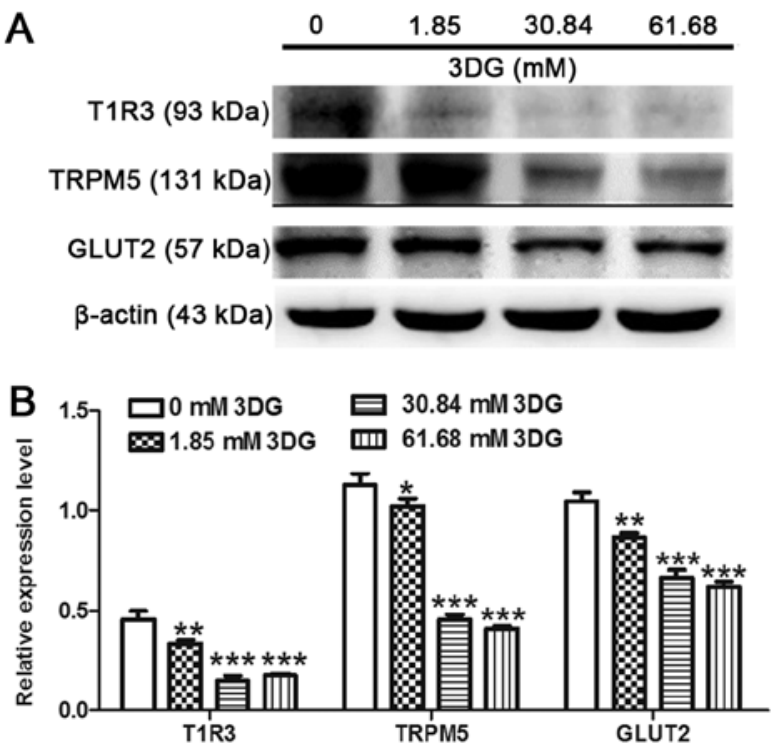

Figure 3. Acute exposure of INS-1 cells to 3DG at $25.5 \mathrm{mM}$ glucose for $1 \mathrm{~h}$ downregulates the sweet taste receptor signaling pathway. INS-1 cells were incubated for $1 \mathrm{~h}$ with $25.5 \mathrm{mM}$ glucose in the absence or presence of 3DG at $1.85,30.84$ or $61.68 \mathrm{mM}$. (A) Cells were incubated with $5.6 \mathrm{mM}$ glucose for $1.5 \mathrm{~h}$ and the protein expression levels of T1R3, TRPM5 and GLUT2 were measured. (B) Protein expression levels of T1R3, TRPM5 and GLUT2, as assessed by densitometry. ${ }^{*} \mathrm{P}<0.05,{ }^{* *} \mathrm{P}<0.01,{ }^{* * *} \mathrm{P}<0.001$ vs. $0 \mathrm{mM}$ 3DG. $\mathrm{n}=3$. 3DG, 3-deoxyglucosone; T1R3, taste 1 receptor member 3; TRPM5, transient receptor potential cation channel subfamily M member 5; GLUT2, glucose transporter 2.

(Fig. 4B and C). The protein expression levels of T1R3, TRPM5 and GLUT2 in islets collected from rats treated with $50 \mathrm{mg} / \mathrm{kg} 3 \mathrm{DG}+0.5 \mathrm{~g} / \mathrm{kg}$ glucose were significantly reduced compared with rats treated with $0.5 \mathrm{~g} / \mathrm{kg}$ glucose and $0.9 \%$ saline. The present results suggested that insulin secretion at $25.5 \mathrm{mM}$ glucose stimulation was impaired, and the protein expression levels of members of the STR signaling pathway were downregulated in islets of rats exhibiting acute glucose intolerance induced by acute exposure to 3DG, consistently with our aforementioned in vitro results (Figs. 2 and 3).

\section{Discussion}

In the present study, the inhibition of the STRs pathway with lactisole in INS- 1 rat $\beta$-cells was identified to decrease insulin secretion following stimulation with a high concentration of glucose $(25.5 \mathrm{mM})$. Furthermore, the present results suggested that acute exposure of INS-1 cells to pathologically relevant concentrations of 3DG at $25.5 \mathrm{mM}$ glucose inhibited insulin secretion. Accordingly, islets from rats collected $2 \mathrm{~h}$ after treatment with $50 \mathrm{mg} / \mathrm{kg} 3 \mathrm{DG}+0.5 \mathrm{~g} / \mathrm{kg}$ glucose i.v. exhibited a reduction in insulin secretion after stimulation with $25.5 \mathrm{mM}$ glucose. Importantly, acute exposure of INS-1 cells to 3DG at $25.5 \mathrm{mM}$ glucose for $1 \mathrm{~h}$ decreased the protein expression levels T1R3, a subunit of STRs, and TRPM5 and GLUT2, two factors downstream of the STRs signaling pathway. Notably, islet tissues collected from rats treated with 3DG showed a similar downregulation. The present results suggested that acute exposure to pathologically relevant concentrations of 3DG inhibited insulin secretion from $\beta$-cells in the presence of $25.5 \mathrm{mM}$ glucose by, at least in part, downregulating the STR signaling pathway.
A previous study demonstrated that the plasma levels of 3DG in non-diabetic elderly subjects vary between 0.049 and $4.54 \mathrm{mM}$ with a median value of $0.27 \mathrm{mM}$ and a 95 th percentile of $2.79 \mathrm{mM}$ (15). A previous study observed that plasma-free 3DG levels in streptozotcin-induced diabetic rats was increased by $\sim 2$-fold $(0.92 \pm 0.13 \mathrm{mM})$ compared with normal rats $(0.38 \pm 0.069 \mathrm{mM})(28)$. Our previous study, to the best of our knowledge, was the first to demonstrate that the plasma levels of 3DG increased 2 -fold $(0.47-0.73 \mathrm{mM})$ following administration of $50 \mathrm{~kg} / \mathrm{kg}$ 3DG i.g. for 2 weeks in mice compared with normal mice $(0.22 \pm 0.083 \mathrm{mM})$, and increased circulating levels of 3DG were identified to be involved in the development of prediabetes (18). Additionally, our previous study identified that pathologically relevant plasma levels of 3DG in rats were induced with a single i.v. injection of 3DG (50 mg/kg) (19). The plasma levels of $3 \mathrm{DG}$ peaked at $15 \mathrm{~min}$ after injection $(102.86 \pm 19.48 \mathrm{mM})$ and declined to $11.34 \pm 3.6 \mathrm{mM}$ after $1 \mathrm{~h}$. However, the 3DG levels were maintained at significantly increased levels for $\geq 2 \mathrm{~h}(8.7 \pm 0.6 \mathrm{mM})$ (19). INS-1 cells were derived from $\mathrm{X}$-ray-induced rat insulinoma cells, which were previously used as an in vitro model of $\beta$-cells due to their insulin secretion capacity following stimulation with glucose (29). The present results suggested that insulin secretion of INS-1 cells at $25.5 \mathrm{mM}$ glucose stimulation increased 1.6-fold compared with basal glucose stimulation (5.6 mM), consistently with previous studies $(30,31)$. Therefore, insulin secretion and the expression of component of the STR pathway were investigated in INS-1 $\beta$-cells under pathological levels of 3DG (30.84 and $61.68 \mathrm{mM}$ ) at $25.5 \mathrm{mM}$ glucose. Additionally, the expression levels of components of the STR pathway were previously identified to be downregulated, and STR-mediated glucagon-like peptide 1 secretion was identified to be reduced in STC-1 L-cells in response to acute exposure to $1.85 \mathrm{mM}$ $3 \mathrm{DG}$ for $1 \mathrm{~h}$ at $25 \mathrm{mM}$ glucose (24). Therefore, in the present study, the effects of $1.85 \mathrm{mM} 3 \mathrm{DG}$ at $25.5 \mathrm{mM}$ glucose on insulin secretion and on the expression levels of members of the STR pathway were examined in INS-1 cells.

Previous studies demonstrated that, following inhibition of the STR signaling pathway, pancreatic $\beta$-cells stimulated by high concentrations of glucose exhibit a reduction of insulin secretion $(7,9)$. Lactisole is a synthetic compound that is used to evaluate the function and physiological roles of the STR pathway in human (32). Previous studies observed that lactisole may be used for investigating the role of STRs in rodents $(32,33)$. The present study suggested that inhibition of STRs with lactisole significantly suppressed insulin secretion by INS-1 $\beta$-cells following stimulation with $25.5 \mathrm{mM}$ glucose. In fact, after $1 \mathrm{~h}$ of treatment with lactisole, insulin secretion stimulated by $25.5 \mathrm{mM}$ glucose was decreased compared with the control group. The present results are consistent with a previous study investigating the effect of lactisole in reducing insulin secretion from MIN6 $\beta$-cells stimulated by $25 \mathrm{mM}$ glucose (32). Interestingly, the STRs expressed in $\beta$-cells are involved in inhibiting the basal insulin secretion (23). Pharmacological inhibition of STRs with lactisole in human islets induces basal insulin hypersecretion at short-term fasting glucose concentrations (23). Consistently with this previous study (23), the present study identified that basal insulin secretion at $5.6 \mathrm{mM}$ glucose increased in INS-1 rat $\beta$-cells after $1 \mathrm{~h}$ of treatment with the STR inhibitor lactisole. 
A
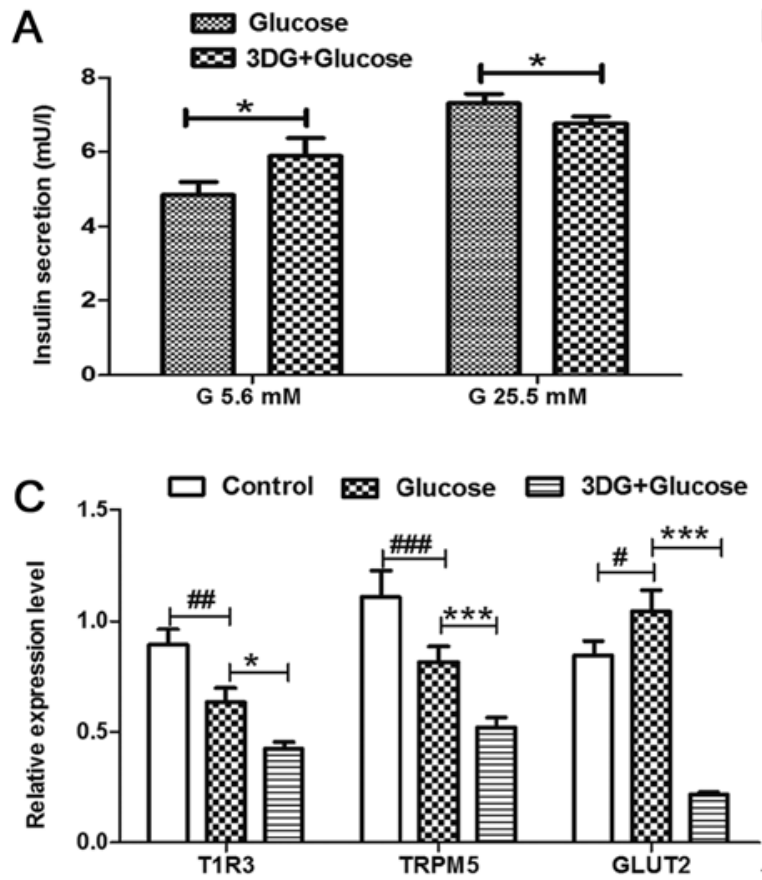

B

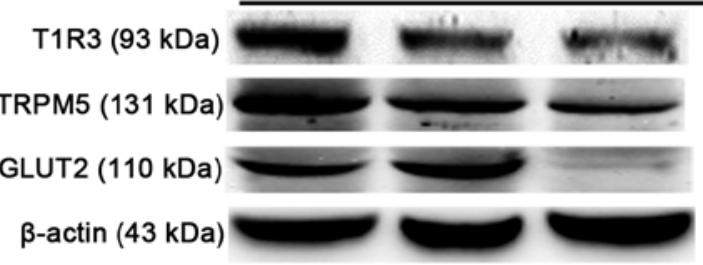

Figure 4. Impairment of insulin secretion and downregulation of the sweet taste receptor signaling pathway in islets of rats with acute glucose intolerance induced by 3DG. After overnight fasting, rats were treated with physiological saline, $0.5 \mathrm{~g} / \mathrm{kg}$ glucose i.v. or $50 \mathrm{mg} / \mathrm{kg} 3 \mathrm{DG}+0.5 \mathrm{~g} / \mathrm{kg}$ glucose i.v. (A) Pancreatic islets were collected from rats $2 \mathrm{~h}$ after treatment and were incubated in RPMI-1640 containing $11.2 \mathrm{mM}$ glucose. Next, islets were incubated with $5.6 \mathrm{mM}$ glucose for $1.5 \mathrm{~h}$ or with $25.5 \mathrm{mM}$ glucose for $1 \mathrm{~h}$. Then, the insulin concentration in the supernatant was measured. $\mathrm{n}=6$. (B) Islets were isolated $2 \mathrm{~h}$ after treatment with physiological saline, $0.5 \mathrm{~g} / \mathrm{kg}$ glucose i.v. or $50 \mathrm{mg} / \mathrm{kg} 3 \mathrm{DG}+0.5 \mathrm{~g} / \mathrm{kg}$ glucose i.v. and processed for the analysis of the protein expression levels of T1R3, TRPM5 and GLUT2 by western blotting. (C) Protein expression levels of T1R3, TRPM5 and GLUT2, as assessed by densitometry. ${ }^{*}<<0.05$, ${ }^{* * *} \mathrm{P}<0.001$ as indicated. ${ }^{\#} \mathrm{P}<0.05,{ }^{\# \#} \mathrm{P}<0.01,{ }^{\# \#} \mathrm{P}<0.001$ as indicated $(\mathrm{n}=3)$. G, gluocse; i.v., intravenously; 3DG, 3-deoxyglucosone; T1R3, taste 1 receptor member 3; TRPM5, transient receptor potential cation channel subfamily M member 5; GLUT2, glucose transporter 2.

The present results suggested that lactisole may be a useful pharmacological tool to assess the function of STRs in INS-1 cells. The present results suggested that under basal conditions, the STRs on the surface of $\beta$-cells may be able to sense the level of glucose, leading to a decrease in the basal insulin secretion, preventing hypoglycemia. Under stimulated conditions, the STRs on the surface of $\beta$-cells are activated by the increase in circulating glucose, and mediate insulin secretion, restoring physiological plasma glucose levels (23). Although the molecular mechanisms underlying STR-mediated inhibition of basal insulin secretion are not fully understood, it is possible that basal insulin hypersecretion is a typical characteristic of the function of STRs in $\beta$-cells.

In the present study, INS-1 cells were treated with 3DG following the same experimental conditions used to investigate the role of lactisole, and acute exposure to 3DG in INS-1 cells or in islets isolated from rats treated with $50 \mathrm{mg} / \mathrm{kg} 3 \mathrm{DG}+$ $0.5 \mathrm{~g} / \mathrm{kg}$ glucose i.v. not only resulted in a reduction in insulin secretion following stimulation with $25.5 \mathrm{mM}$ glucose, but also induced basal insulin hypersecretion at $5.6 \mathrm{mM}$ glucose, consistently with the treatment with the STR inhibitor lactisole. Therefore, the present results suggested that acute exposure to pathologically relevant plasma levels of 3DG impaired the STR-mediated regulation of insulin secretion in pancreatic $\beta$-cells. The present results are consistent with the effects that were previously reported for methylglyoxal, a highly reactive $\alpha$-dicarbonyl compound (34). Elmhiri et al (34) hypothesized that the acute effect of methylglyoxal on insulin secretion may be related to the metabolic state of $\beta$-cells. STRs expressed in $\beta$-cells serve distinct roles in finely tuning insulin secretion under basal and glucose-stimulated conditions. Therefore, it is possible that STRs may be key molecules involved in methylglyoxal regulation of insulin secretion. Accordingly, in the present study, acute exposure to 3DG showed deleterious effects on the STR-mediated regulation of insulin secretion in pancreatic $\beta$-cells.

The present results suggested that 3DG exhibited deleterious effects on STR-mediated insulin secretion. In fact, acute exposure to pathologically relevant concentration of 3DG in the presence of $25.5 \mathrm{mM}$ glucose downregulated the protein expression levels of the STR subunit T1R3 and of other components of the canonical STR signaling pathway (35), such as TRPM5 and GLUT2. Collectively, acute exposure to pathologically relevant plasma levels of $3 \mathrm{DG}$ at $25.5 \mathrm{mM}$ glucose downregulated the protein expression level of T1R3, impairing the effects of STRs on the regulation of insulin secretion by pancreatic $\beta$-cells. The present results are not sufficient to understand the mechanism underlying the 3DG-mediated T1R3 downregulation; however, the mechanisms underlying 3DG function may involve several processes. 3DG was previously reported to react with the $\mathrm{N}$-terminal amino group of nucleic acids (36), leading to inhibition of transcription and causing a decrease in gene expression. Carbonylation of proteins is a permanent modification that may alter the function or structure of proteins, affecting their downstream signaling pathway (37). The accumulation of the dicarbonyl compound 3DG was previously reported to induce carbonyl stress, increasing the carbonylation of proteins (38). The 
ability of 3DG to downregulate the protein expression level of T1R3 may be mediated by the carbonyl stress caused by 3DG. Therefore, further studies are required to investigate the mechanism underlying the 3DG-mediated downregulation of the protein expression level of T1R3 following exposure to high concentrations of glucose.

Since STR-mediated regulation of insulin secretion was identified in the present study to be impaired in islets collected from rats treated with 3DG, the expression levels of members of the STR signaling pathway were investigated. At $2 \mathrm{~h}$ after administration of $0.5 \mathrm{~g} / \mathrm{kg}$ glucose i.v., the plasma levels of glucose declined to levels only slightly higher than the basal glucose levels (19). GLUT2 is a glucose-sensitive gene (39), and GLUT2 expression level in islet tissues from rats $2 \mathrm{~h}$ after acute administration of $0.5 \mathrm{~g} / \mathrm{kg}$ glucose i.v. increased compared with islets from fasting rats. Interestingly, the protein expression levels of T1R3 and TRPM5 in islet tissues harvested $2 \mathrm{~h}$ after acute administration of $0.5 \mathrm{~g} / \mathrm{kg}$ glucose i.v. were markedly decreased compared with fasting rats. Possibly, under high glucose levels, the STR-mediated regulation of basal insulin secretion may not be immediately detected. Furthermore, the upregulation of T1R3 expression in the islets of fasting rats suggested a role of STRs in sensing circulating glucose in modulating basal insulin secretion. Therefore, the downregulated expression levels of T1R3, TRPM5 and GLUT2 in islet tissues collected from rats $2 \mathrm{~h}$ after acute administration of $50 \mathrm{mg} / \mathrm{kg} 3 \mathrm{DG}+0.5 \mathrm{~g} / \mathrm{kg}$ glucose i.v. could be responsible for the impaired STR-mediated insulin secretion in islets from 3DG-treated rats. Additionally, since GLUT2 expression can be regulated by insulin (40), the downregulation of GLUT2 expression may be consistent with our previous results suggesting that $50 \mathrm{mg} / \mathrm{kg} 3 \mathrm{DG}$ i.v. administered to rats impaired the insulin signaling pathway (19). GLUT2 is one of the main factors required for glucose-dependent insulin secretion 4(41). Therefore, the reduced insulin secretion at $25.5 \mathrm{mM}$ glucose following treatment with 3DG identified in the present study in INS-1 cells and islets could be caused, at least in part, by a decrease in GLUT2 expression. Collectively, the impairment in insulin secretion and in the STR signaling pathway suggested that elevated circulating levels of 3DG may be involved in the development of $\beta$-cell dysfunction.

To the best of our knowledge, the present study is the first to provide evidence that acute exposure to pathologically relevant levels of 3DG at high physiological glucose levels downregulated the STR signaling pathway in pancreatic $\beta$-cells. The downregulation of the STR signaling pathway was involved in the acute effect of $3 \mathrm{DG}$ on the regulation of insulin secretion. The present results suggested a novel mechanism linking the impairment of $\beta$-cell function with the increase in the circulating levels of 3DG via the downregulation of the STR signaling pathway. The present findings suggested that the STRs expressed in $\beta$-cells may be a promising therapeutic target to prevent and treat diabetes. Furthermore, the present results suggested that STRs expressed on $\beta$-cell may be a promising therapeutic target to prevent and treat diabetes.

\section{Acknowledgements}

Not applicable.

\section{Funding}

The present work was supported by Grants from Jiangsu Province's Key Provincial Talents Program (grant nos. QNRC2016259 and QNRC2016252), Suzhou Science and Technology Department (grant no. SYSD2017191) and Suzhou TCM Hospital Affiliated to Nanjing University of Chinese Medicine (grant no. YQN2016006).

\section{Availability of data and materials}

All data generated or analyzed during the present study are included in this published article.

\section{Authors' contributions}

All authors contributed to the concept and design of the study, and all authors interpreted the data. XDS, LZ, GRJ, MS, GQL, FW, LRZ and HF collected and analyzed the data. XDS, LZ and GRJ drafted the manuscript. GRJ reviewed the manuscript for important intellectual content. All authors revised the article and approved the final manuscript. GRJ is responsible for the integrity of the work as a whole.

\section{Ethics approval and consent to participate}

All the animal experimental procedures were conducted in compliance with The Directive 2010/63/EU. The present study was approved by The Local Committee on Ethics of Animal Experiments of Suzhou TCM Hospital Affiliated to Nanjing University of Chinese Medicine.

\section{Patient consent for publication}

Not applicable.

\section{Competing interests}

The authors declare that they have no competing interests.

\section{References}

1. Schuit FC, Huypens P, Heimberg H and Pipeleers DG: Glucose sensing in pancreatic beta-cells: A model for the study of other glucose-regulated cells in gut, pancreas, and hypothalamus. Diabetes 50: 1-11, 2001

2. Kojima I, Medina J and Nakagawa Y: Role of the glucose-sensing receptor in insulin secretion. Diabetes Obes Metab 1 (Suppl 19): S54-S62, 2017.

3. Nelson G, Hoon MA, Chandrashekar J, Zhang Y, Ryba NJ and Zuker CS: Mammalian sweet taste receptors. Cell 106: 381-390, 2001.

4. Margolskee RF: Molecular mechanisms of bitter and sweet taste transduction. J Biol Chem 277: 1-4, 2002.

5. Depoortere I: Taste receptors of the gut: Emerging roles in health and disease. Gut 63: 179-190, 2014.

6. Kyriazis GA, Soundarapandian MM and Tyrberg B: Sweet taste receptor signaling in beta cells mediates fructose-induced potentiation of glucose-stimulated insulin secretion. Proc Natl Acad Sci USA 109: E524-E532, 2012.

7. Nakagawa Y, Nagasawa M, Yamada S, Hara A, Mogami H, Nikolaev VO, Lohse MJ, Shigemura N, Ninomiya Y and Kojima I: Sweet taste receptor expressed in pancreatic beta-cells activates the calcium and cyclic AMP signaling systems and stimulates insulin secretion. PLoS One 4: e5106, 2009. 
8. Nakagawa Y, Nagasawa M, Mogami H, Lohse M, Ninomiya Y and Kojima I: Multimodal function of the sweet taste receptor expressed in pancreatic $\beta$-cells: Generation of diverse patterns of intracellular signals by sweet agonists. Endocr J 60: 1191-1206, 2013.

9. Nakagawa Y, Ohtsu Y, Nagasawa M, Shibata H and Kojima I: Glucose promotes its own metabolism by acting on the cell-surface glucose-sensing receptor T1R3. Endocr J 61: 119-131, 2014.

10. Niwa T: 3-Deoxyglucosone: Metabolism, analysis, biological activity, and clinical implication. J Chromatogr B Biomed Sci Appl 731: 23-36, 1999.

11. Degen J, Beyer H, Heymann B, Hellwig M and Henle T: Dietary influence on urinary excretion of 3-deoxyglucosone and its metabolite 3-deoxyfructose. J Agric Food Chem 62: 2449-2456, 2014.

12. Brings S, Fleming T, Freichel M, Muckenthaler MU, Herzig S and Nawroth PP: Dicarbonyls and advanced glycation end-products in the development of diabetic complications and targets for intervention. Int J Mol Sci 18: E984, 2017.

13. Lal S, Kappler F, Walker M, Orchard TJ, Beisswenger PJ, Szwergold BS and Brown TR: Quantitation of 3-deoxyglucosone levels in human plasma. Arch Biochem Biophys 342: 254-260, 1997.

14. Hamada Y, Nakamura J, Fujisawa H, Yago H, Nakashima E, Koh N and Hotta N: Effects of glycemic control on plasma 3 -deoxyglucosone levels in NIDDM patients. Diabetes Care 20: 1466-1469, 1997.

15. Jiang G, Zhang L, Ji Q, Wang F, Xu H, Huang F and Wang C: Accumulation of plasma 3-deoxyglucosone impaired glucose regulation in Chinese seniors: Implication for senile diabetes? Diabetes Metab Syndr 6: 140-145, 2012.

16. Zhang L, Song X, Zhou L, Liang G, Xu H, Wang F, Huang F and Jiang G: Accumulation of intestinal tissue 3-deoxyglucosone attenuated GLP-1 secretion and its insulinotropic effect in rats. Diabetol Metab Syndr 8: 78, 2016.

17. Wang F, Zhou L, Song X, Liang G, Xu H, Zhang L and Jiang G: Acute reduction of incretin effect and glucose intolerance in rats by single intragastric administration of 3-deoxyglucosone. Exp Clin Endocrinol Diabetes 125: 4-11, 2017.

18. Zhang L, Zhou L, Song X, Liang G, Xu Z, Wang F, Huang F and Jiang G: Involvement of exogenous 3-deoxyglucosone in $\beta$-cell dysfunction induces impaired glucose regulation. Mol Med Rep 16: 2976-2984, 2017.

19. Liang G, Song X, Xu H, Wang F, Zhang L, Zhou L and Jiang G: 3-Deoxyglucosone induced acute glucose intolerance in sprague-dawley rats: Involvement of insulin resistance and impaired $\beta$-cell function. Exp Clin Endocrinol Diabetes 124: 431-436, 2016.

20. Maessen DE, Hanssen NM, Scheijen JL, van der Kallen CJ, van Greevenbroek MM, Stehouwer $C D$ and Schalkwijk CG: Post-glucose load plasma $\alpha$-dicarbonyl concentrations are increased in individuals with impaired glucose metabolism and type 2 diabetes: The CODAM study. Diabetes Care 38: 913-920, 2015.

21. Feng R, Qian C, Liu Q, Jin Y, Liu L, Li S, Liao Y, Zhou H, Liu W, Rayner CK and Ma J: Expression of sweet taste receptor and gut hormone secretion in modeled type 2 diabete. Gen Comp Endocrinol 252: 142-149, 2017.

22. Medina A, Nakagawa Y, Ma J, Li L, Hamano K, Akimoto T, Ninomiya Y and Kojima I: Expression of the glucose-sensing receptor T1R3 in pancreatic islet: Changes in the expression levels in various nutritional and metabolic states. Endocr J 61: 797-805, 2014.

23. Kyriazis GA, Smith KR, Tyrberg B, Hussain T and Pratley RE: Sweet taste receptors regulate basal insulin secretion and contribute to compensatory insulin hypersecretion during the development of diabetes in male mice. Endocrinology 155 : 2112-2121, 2014
24. Wang F, Song X, Zhou L, Liang G, Huang F, Jiang G and Zhang L: The downregulation of sweet taste receptor signaling in enteroendocrine L-cells mediates 3-deoxyglucosone-induced attenuation of high glucose-stimulated GLP-1 secretion. Arch Physiol Biochem 124: 430-435, 2018.

25. Kato H, van Chuyen N, Shinoda T, Sekiya F and Hayase F: Metabolism of 3-deoxyglucosone, an intermediate compound in the maillard reaction, administered orally or intravenously to rats. Biochim Biophys Acta 1035: 71-76, 1990.

26. Liang G, Wang F, Song X, Zhang L, Qian Z and Jiang G: 3-Deoxyglucosone induces insulin resistance by impairing insulin signaling in HepG2 cells. Mol Med Rep 13: 4506-4512, 2016.

27. Chlebus M, Guillen J and Prins JB: Directive 2010/63/EU: Facilitating full and correct implementation. Lab Anim 50: 151, 2016.

28. Yamada H, Miyata S, Igaki N, Yatabe H, Miyauchi Y, Ohara T, Sakai M, Shoda H, Oimomi $M$ and Kasuga M: Increase in 3-deoxyglucosone levels in diabetic rat plasma. Specific in vivo determination of intermediate in advanced Maillard reaction. J Biol Chem 269: 20275-20280, 1994.

29. Asfari M, Janjic D, Meda P, Li G, Halban PA and Wollheim CB: Establishment of 2-mercaptoethanol-dependent differentiated insulin-secreting cell lines. Endocrinology 130: 167-178, 1992.

30. Kang MY, Oh TJ and Cho YM: Glucagon-like peptide-1 increases mitochondrial biogenesis and function in INS-1 rat insulinoma cells. Endocrinol Metab (Seoul) 30: 216-220, 2015.

31. Bo J, Xie S, Guo Y, Zhang C, Guan Y, Li C, Lu J and Meng QH Methylglyoxal impairs insulin secretion of pancreatic $\beta$-Cells through increased production of ROS and mitochondrial dysfunction mediated by upregulation of UCP2 and MAPKs. J Diabetes Res 2016: 2029854, 2016.

32. Hamano K, Nakagawa Y, Ohtsu Y, Li L, Medina J, Tanaka Y, Masuda K, Komatsu M and Kojima I: Lactisole inhibits the glucose-sensing receptor T1R3 expressed in mouse pancreatic $\beta$-cells. J Endocrinol 226: 57-66, 2015.

33. Zhou L, Huang W, Xu Y, Gao C, Zhang T, Guo M, Liu Y, Ding J, Qin L, Xu Z, et al: Sweet taste receptors mediated ROS-NLRP3 inflammasome signaling activation: Implications for diabetic nephropathy. J Diabetes Res 2018: 7078214, 2018.

34. Elmhiri G, Barella LF, Vieau D, Camous S, Mathias PC and Abdennebi-Najar L: Acute exposure to a precursor of advanced glycation end products induces a dual effect on the rat pancreatic islet function. Int J Endocrinol 2014: 378284, 2014.

35. Mace OJ, Affleck J, Patel N and Kellett GL: Sweet taste receptors in rat small intestine stimulate glucose absorption through apical GLUT2. J Physiol 582: 379-392, 2007.

36. Ashraf JM, Shahab U, Tabrez S, Lee EJ, Choi I, Aslam Yusuf M and Ahmad S: DNA glycation from 3-deoxyglucosone leads to the formation of AGEs: Potential role in cancer auto-antibodies. Cell Biochem Biophys 74: 67-77, 2016.

37. Hecker $M$ and Wagner AH: Role of protein carbonylation in diabetes. J Inherit Metab Dis 41: 29-38, 2018.

38. Aldini G, Dalle-Donne I, Facino RM, Milzani A and Carini M: Intervention strategies to inhibit protein carbonylation by lipoxidation-derived reactive carbonyls. Med Res Rev 27: 817-868, 2007.

39. Thorens B: GLUT2, glucose sensing and glucose homeostasis. Diabetologia 58: 221-232, 2015.

40. Song Z, Wang H, Zhu L, Han M, Gao Y, Du Y and Wen Y: Curcumin improves high glucose-induced INS-1 cell insulin resistance via activation of insulinsignaling. Food Funct 6: 461-469, 2015.

41. Guillam MT, Hümmler E, Schaerer E, Yeh JI, Birnbaum MJ, Beermann F, Schmidt A, Dériaz N and Thorens B: Early diabetes and abnormal postnatal pancreatic islet development in mice lacking Glut-2. Nat Genet 17: 327-330, 1997. 